\title{
ANALYSIS OF INDICATORS AND COST OF WORLD CLASS MAINTENANCE (WCM) IN FOREST MACHINES
}

\author{
Carlos Cezar Cavassin Diniz*, Eduardo da Silva Lopes², Gabriel de Magalhães Miranda², Henrique Soares \\ Koehler ${ }^{1}$, Eduardo Kremer Custodio de Souza ${ }^{3}$ \\ ${ }^{1}$ Federal University of Paraná, Postgraduation Program in Forest Engineering, Curitiba, State of Paraná, Brazil - carlos.diniz@ufpr.br*, \\ koehler@ufpr.br \\ 2State University of the Midwest, Postgraduate Program in Forest Sciences, Irati, State of Paraná, Brazil - eslopes@unicentro.br, \\ gmiranda@unicentro.br \\ ${ }^{3}$ Klabin SA, Telemâco Borba, State of Paraná, Brazil - ekcsouza@klabin.com.br
}

Received for publication: 19/06/2018 - Accepted for publication: 30/08/2018

\begin{abstract}
Resumo
Análise de indicadores e custos da manutenção de classe mundial (WCM) em máquinas florestais. O estudo foi realizado em uma empresa florestal localizada no Estado do Paraná, Brasil, nas máquinas feller buncher, skidder e harvester. Foram avaliados os seguintes indicadores: disponibilidade mecânica, tempo médio entre falhas, tempo médio de reparo, índice de manutenção proativa e custos de manutenção, a partir de dados obtidos por um período de 18 meses, contemplando os estágios de implantação, amadurecimento e estabilização do WCM. Os resultados mostraram aumento na disponibilidade mecânica das máquinas de corte e arraste a partir do estágio de implantação. O tempo médio entre falhas aumentou a partir do estágio de implantação, passando de 31,59 horas para 37,01 horas no estágio de estabilização. Quanto ao tempo médio de reparos, o skidder e o harvester apresentaram aumento de $25,9 \%$ e $18,9 \%$ respectivamente, entretanto, este aumento de tempo representou melhoria na qualidade dos serviços de manutenção, refletidos nos resultados de tempo médio entre falhas. Houve ainda aumento de $31 \%$ no índice de proativa das máquinas estudadas, perfazendo uma redução de $9 \%$ no custo de manutenção entre os estágios de implantação e estabilização.

Palavras-chave: Gestão de manutenção; planejamento; otimização.
\end{abstract}

\begin{abstract}
The study was carried out at a forest company located in the Paraná State, Brazil, with the feller buncher, skidder and harvester. The following indicators were evaluated: mechanical availability, mean time between failures, mean time to repair, proactive maintenance index and maintenance costs, based on data obtained over a period of 18 months, contemplating the stages of implantation, maturation and stabilization of the WCM. The results showed an increase in the mechanical availability of the cutting and skidding machines from the implantation stage. The mean time between failures increased from the implantation stage, from 31.59 hours to 37.01 hours in the stabilization stage. As for the mean time to repairs, skidder and harvester presented an increase of $25.9 \%$ and $18.9 \%$ respectively; however, this increase in time represented an improvement in the quality of maintenance services, reflected in the results of mean time between failures. There was also a $31 \%$ increase in the proactive index of the machines studied, resulting in $9 \%$ reduction in maintenance costs between the deployment and stabilization stages.

Keywords: Maintenance management; planning; optimization.
\end{abstract}

\section{INTRODUCTION}

Mechanization in wood harvesting operations has evolved in the last decades, providing a reduction in labor dependence, improvements in working conditions, higher machines production capacity, standardization of wood quality and supply guarantee to industries (SPINELLI et al., 2009; LEITE et al., 2014).

The tendency towards mechanization increasing of forest harvesting operations is attributed mainly to the need for higher productivity; however, other factors such as safety, environment and costs should also be considered (LeDOUX, 2010). In this sense, researchers infer that forest harvesting activities represent high costs in the forest productive process, and can reach $50 \%$ or more of the industry wood costs, having, possibly, a great economic impact on the forest-based industry (GUEDES et al., 2017).

Lopes et al. (2014) and Silva et al. (2010), studying the extraction and logging operations, respectively, identified that only the cost of mechanical maintenance can represent up to $60 \%$ of forest harvesting machine total cost, being clear the importance of the maintenance sector within the activity of wood harvesting.

Considering the beginning of mechanization since the 90's, every year that passes, forestry machines are being offered with more and more technology, from the simplest to the most complex components, involving the electrical, hydraulic and mechanical parts. Thus, it becomes necessary to use an efficient maintenance management model as well as the use of specialized manpower, allowing the maintenance of assets in forest operations.

FLORESTA, Curitiba, PR, v. 49, n. 3, p. 533 - 542, jul/set 2019.

Dinz, C. C. C. et.al.

ISSN eletrônico 1982-4688

DOI: $10.5380 /$ rf.v49 i3.60013 
Kardec et al. (2002) and Muchiri et al. (2011) infer that maintenance can be defined as the combination of all administrative and technical activities aimed at the maintenance of machines, facilities and other physical assets under operational conditions while maintaining their activities purposes. Moreover, Paccola (2017) infers that, in addition to providing reliability and maintainability of equipment, maintenance consists of managing teams and other resources that are available in the company and in the maintenance area.

Among the maintenance programs, World Class Maintenance (WCM) can be mentioned which, according to Yamashina (2000), aims to achieve world class maintenance through process leadership, involving good practices from others maintenance programs such as Total Productive Maintenance (TPM). Mishra et al. (2015) commented that WCM proposes the promotion of culture changes in relation to reactive maintenance methods and the optimization of maintenance operations through improvements in the process in order to achieve zero failures.

As one of the fundamental activities of the productive process, preventive maintenance, one of the bases of WCM, exists to eliminate or reduce corrective interventions (KARDEC et al., 2002). Yet, Dario et al. (2014) mention that it is also necessary to prioritize the increased availability and reliability, since these are fundamental factors for the performance of company processes. For this, it is necessary to use measurement indicators, verifying if it is adequate to the goals and the proposed deadlines.

Due to the importance of the mechanical maintenance activity in the wood harvesting sector, we emphasize the need to carry out studies aimed at the organization, rationalization, identification of operational factors and interference with the cost of maintaining wood harvesting machines in search of improvement to be continued. Therefore, the present study aimed to analyze the indicators and costs of World Class Maintenance (WCM) in wood harvesting machines, contributing to the maintenance management process.

\section{MATERIAL AND METHODS}

The research was executed in a forest company located in the municipality of Telêmaco Borba, state of Paraná, Brazil. The climate of the region was classified as a transition between $\mathrm{Cfa}$ and $\mathrm{Cfb}$, humid subtropical, with average temperature varying between $16.3^{\circ} \mathrm{C}$ and $23.2^{\circ} \mathrm{C}$ and average annual rainfall between 1.478 and $1.700 \mathrm{~mm}$ with average altitude of $750 \mathrm{~m}$ (Barbosa et al., 2007).

The study was carried out using data from the machines performing wood harvesting in stands of Eucalyptus grandis and Pinus taeda with age of 7 and 17 years old and individual mean volume of 0.36 to 0.42 $\mathrm{m}^{3}$ respectively, in a shallow cutting regime and smooth undulated relief.

The study was conducted in a wood harvesting company module, in the full tree system, in which the trees were felled and stacked by the feller buncher, and then dragged to the margins of the stands by skidder, and finally processed into logs by the harvester processor (Figure 1).
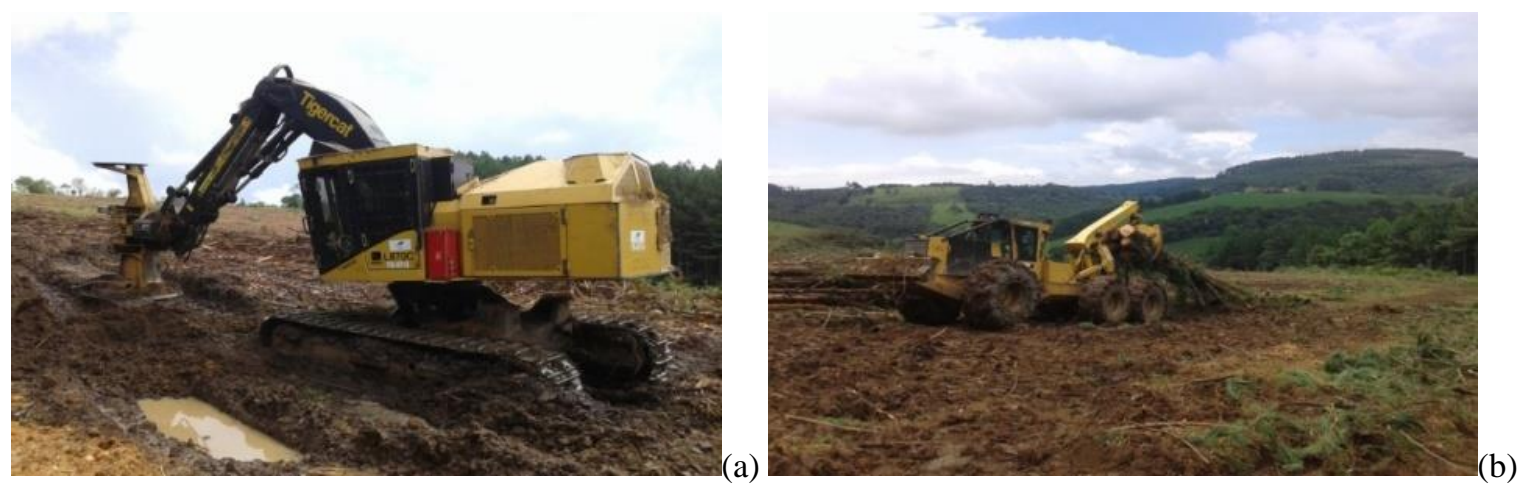


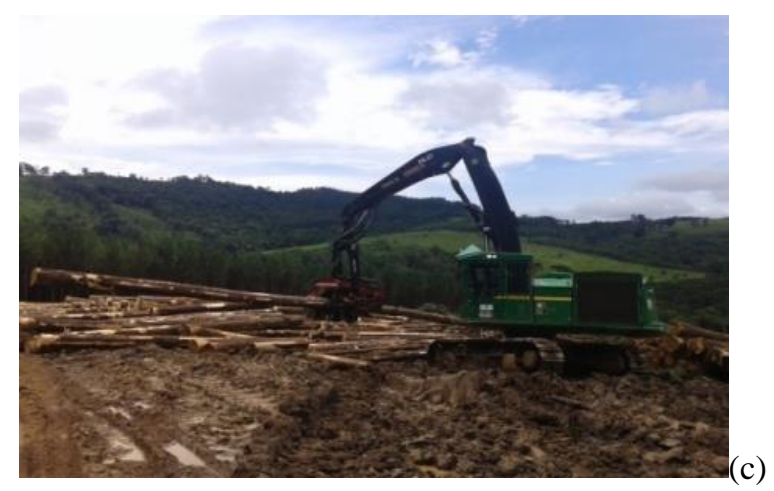

Figura 1. Feller buncher (a), skidder (b) e harvester processador (c) avaliados no estudo. Figure 1. Feller buncher (a), skidder (b) and harvester processor (c) evaluated in the study.

The feller buncher had nominal horsepower of $300 \mathrm{hp}$, operating weight of $38 \mathrm{t}$ and hourmeter of 4.977 $\mathrm{h}$; the skidder had a nominal horsepower of $250 \mathrm{hp}$, operating weight of $22.7 \mathrm{t}$, equipped with a claw of $1.95 \mathrm{~m}^{2}$ of floor space and hourmeter of $1.501 \mathrm{~h}$; while the harvester processor had nominal horsepower of $294 \mathrm{hp}$, operating weight of $33.4 \mathrm{t}$ and hourmeter of $1.758 \mathrm{~h}$.

The data of the machines at the operational timber harvesting fronts were obtained daily in the three work shifts over a period of 18 months. The activities performed with the introduction of WCM are presented in Table 1 .

Tabela 1. Atividades de manutenção adotadas com a implantação do WCM.

Table 1. Maintenance activities adopted with WCM implementation.

\begin{tabular}{ll}
\hline \multicolumn{1}{c}{ Activities } & \multicolumn{1}{c}{ Description } \\
\hline Corrective maintenance & $\begin{array}{l}\text { Immediate correction of any failure or breakdowns occurring in the field, such } \\
\text { as hoses bursting, broken pins, gap adjustments, bearing change, etc. }\end{array}$ \\
\hline $\begin{array}{l}\text { Preventive maintenance } \\
\text { lubrication }\end{array}$ & $\begin{array}{l}\text { of } \\
\text { Revisions for the exchange of oils and filters, according to the manuals of the } \\
\text { machines and definition of the maintenance sector. }\end{array}$ \\
\hline Failures Analysis & $\begin{array}{l}\text { Analysis of machine components performed by multidisciplinary team, } \\
\text { composed of people with knowledge of the process and method for definitive } \\
\text { problem solution or its mitigation. }\end{array}$ \\
\hline Preventive maintenance & $\begin{array}{l}\text { Cycle of maintenances realized during eight weeks in all the machines, being } \\
\text { each week certain components were reviewed } .\end{array}$ \\
\hline Strategic reviews & $\begin{array}{l}\text { Revisions of the machines performed by mechanics in intervals of three } \\
\text { weeks, when during two days are carried out the heavy and complex works of } \\
\text { welds. }\end{array}$ \\
\hline
\end{tabular}

The following indicators were analyzed: Mechanic Availability (MA), Mean Time Between Failures (MTBF), Mean Time of Repair (MTTR), Proactive Maintenance Index (PMI) and Maintenance Cost (MC).

The MA, defined as the percentage of the scheduled service time in which the machine was available to perform a given activity, disregarding the maintenance time, was obtained by the equation used by Guedes et al. (2017).

$$
\mathrm{MA}=\frac{\mathrm{HW}-\mathrm{HM}}{\mathrm{HW}} \times 100
$$

in which: MA = Degree of mechanical availability $(\%) ; \mathrm{HW}=$ Scheduled hours for work; and $\mathrm{HM}=\mathrm{Hours}$ in preventive and corrective maintenance.

The MTBF is defined by the ratio between the total number of hours available for the work in relation to the number of corrective maintenance performed in a given evaluation period, obtained by the following equation (WIENKER et al., 1669, 2016).

$$
\mathrm{MTBF}=\frac{\mathrm{AWH}}{\mathrm{CM}}
$$

FLORESTA, Curitiba, PR, v. 49, n. 3, p. 533 - 542, jul/set 2019.

Dinz, C. C. C. et.al.

ISSN eletrônico 1982-4688

DOI: $10.5380 /$ rf.v49 i3.60013 
in which: $\mathrm{MTBF}=$ Mean time between failures (hours); AWH = Available working hours of the machine; and CM $=$ number of corrective maintenance performed in the period.

The MTTR is defined by the relation between the hours of the corrective maintenance of the machine in relation to the number of corrective maintenance performed in the evaluation period, obtained by the following equation (WIENKER et al., 2016).

$$
\text { MTTR }=\frac{\mathrm{CMH}}{\mathrm{CM}}
$$

in which: MTTR = Average repair time (hours); $\mathrm{CMH}=$ Corrective maintenance hours; and $\mathrm{MC}=$ number of corrective maintenance performed.

The PMI is defined by the percentage of proactive maintenance carried out in the machine, being obtained by the ratio between the proactive maintenance time (preventive character) and the total maintenance time in the machine, obtained by the following equation:

$$
\mathrm{PMI}=\frac{\mathrm{PRMT}}{\mathrm{TMT}} \times 100
$$

in which: $\mathrm{PMI}=$ Reactive index (\%); PRMT = Proactive maintenance time (hours); and TMT = Total maintenance time (hours).

The MC of the machines studied included the cost of personnel, materials, external services and support. The cost of maintenance personnel included expenses with salaries, social charges and benefits provided by the company (profit sharing, training and retraining). The monthly total values were divided by the number of hours worked of the equipments studied.

$$
\mathrm{PC}=\frac{\mathrm{BS}+\mathrm{SC}+\mathrm{SB}}{\mathrm{HW}}
$$

in which: $\mathrm{PC}=$ Maintenance personnel cost $(\mathrm{R} \$ /$ hour $) ; \mathrm{BS}=$ Basic salary $(\mathrm{R} \$) ; \mathrm{SC}=$ Social charges $(\mathrm{R} \$)$; and $\mathrm{SB}$ $=$ Social benefits $(\mathrm{R} \$)$; HW = Number of hours worked in the month.

The cost of maintenance materials refers to the consumption of spare parts of the machines and tools used in the maintenance operation obtained by the following equation:

$$
\mathrm{MTC}=\frac{\mathrm{MT}}{\mathrm{HW}}
$$

in which: $\mathrm{MTC}=$ Material cost $(\mathrm{R} \$ /$ hour$) ; \mathrm{MT}=$ Materials (spare parts and tools) $(\mathrm{R} \$)$ and $\mathrm{HW}=\mathrm{Number}$ of hours worked in the month.

The cost of external services refers to the monthly values of contracts with outsourced companies for the execution of services, such as washing equipment, welding, oil analysis and other activities, which were then divided by the respective hours worked during the evaluation obtained by the equation:

$$
\mathrm{CES}=\frac{\mathrm{CT}}{\mathrm{HW}}
$$

in which: CES = Cost of external services $(\mathrm{R} \$ /$ hour $)$; $\mathrm{CT}=$ Contracts of third parties $(\mathrm{R} \$)$ and $\mathrm{HW}=$ Number of hours worked in the month.

The cost of support was related to the inputs used by the machines, including the infrastructure and the support vehicles (convoy truck, welding cart, warehouse, etc.) of maintenance, obtained by equation:

$$
\mathrm{SC}=\frac{\mathrm{CI}}{\mathrm{HW}}
$$

in which: $\mathrm{SC}=$ Support cost $(\mathrm{R} \$ /$ hour $) ; \mathrm{CI}=$ Cost of supporting infrastructure and HW = Number of hours worked in the month $(\mathrm{h})$. 
The total maintenance cost was obtained by the sum of personnel, materials, services and support costs, calculated by the following equation:

$$
\mathrm{MC}=\mathrm{PC}+\mathrm{MTC}+\mathrm{CES}+\mathrm{CA}
$$

in which: $\mathrm{CM}=$ Machine maintenance cost $(\mathrm{R} \$ / \mathrm{he}) ; \mathrm{PC}=$ Personnel cost $(\mathrm{R} \$ / \mathrm{he})$; $\mathrm{MTC}=$ Material cost $(\mathrm{R} \$ / \mathrm{he})$; $\mathrm{CES}=$ Cost of services $(\mathrm{R} \$ / \mathrm{he})$; and $\mathrm{SC}=$ Support cost $(\mathrm{R} \$ / \mathrm{he})$.

A completely randomized design with factorial arrangement was used, in which nine treatments with six replicates were tested for MA, MTBF, MTTR, PMI and MC indicators. The treatments represented the combination of three machines (feller buncher, skidder and harvester), undergoing three stages of maintenance (implantation, maturation and stabilization).

It is important to clarify that the combination of the machines with the maintenance stages represent the treatments, while the number of repetitions represents the period of time (months) in which the machines were submitted to the WCM, totaling 18 months.

For the MTTR indicator, it was not possible to obtain the information to the implantation stage, in this way, the same type of analysis was performed, however, a total of six treatments with five replications were applied, and the treatments represent the combination of the three machines in two stages (maturing and stabilization).

The results were submitted to the technique of variance analysis and in the cases in which there were significant differences the Tukey test $\left(\mathrm{p}_{\text {value }}<0,05\right)$ was carried out through the program Assistat 7.7 beta.

\section{RESULTS}

The WCM, in general, presented good results, since the feller buncher and skidder presented an increase of MA in relation to WCM implantation period (Figure 2). It can be observed that the machines' MA presented a small variation, and it was not possible to detect significant differences between the stages by the Tukey test ( $p_{\text {value }}$ $<0,05)$.

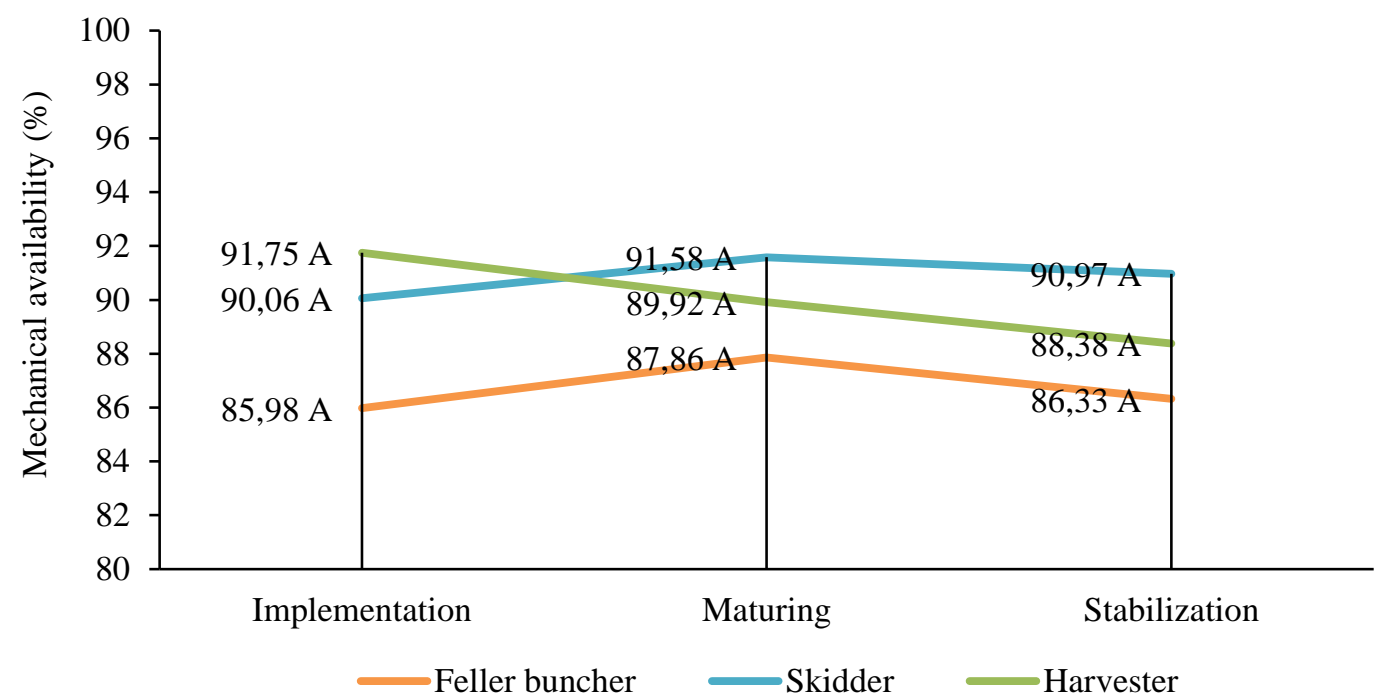

Means followed by the same horizontal letter for each machine studied do not differ statistically by the Tukey test at $5 \%$ probability.

Figura 2. Indicador de DM das máquinas estudadas nos estágios do WCM.

Figure 2. Index of MA of the machines studied in the WCM stages.

The results of the MTBF indicator presented in Table 2 indicate that, in general, the WCM system allows a considerable increase in the fault interval of the studied machines, being evidenced in the skidder, with a $31 \%$ increase, also presenting significant difference by the test of Tukey ( $\left.\mathrm{p}_{\text {value }}<0.05\right)$.

FLORESTA, Curitiba, PR, v. 49, n. 3, p. 533 - 542, jul/set 2019. 
Tabela 2. Indicadores de manutenção das máquinas estudadas nos estágios do WCM.

Table 2. Maintenance index of the machines studied in the WCM stages.

\begin{tabular}{llccc}
\hline \multicolumn{1}{c}{ Machine } & \multicolumn{1}{c}{ Stage } & MTBF (hours) & MTTR (hours) & PMI (\%) \\
\hline \multirow{3}{*}{ Feller Buncher } & Implementation & $24.67 \mathrm{~A}$ & - & $0.31 \mathrm{~B}$ \\
& Maturing & $28.28 \mathrm{~A}$ & $2.70 \mathrm{~A}$ & $0.66 \mathrm{~A}$ \\
& Stabilization & $26.73 \mathrm{~A}$ & $2.50 \mathrm{~A}$ & $0.53 \mathrm{~A}$ \\
\hline \multirow{3}{*}{ Skidder } & Implementation & $31.64 \mathrm{~A}$ & - & $0.33 \mathrm{~B}$ \\
& Maturing & $40.85 \mathrm{~B}$ & $3.14 \mathrm{~A}$ & $0.73 \mathrm{~A}$ \\
& Stabilization & $45.90 \mathrm{~B}$ & $4.24 \mathrm{~A}$ & $0.71 \mathrm{~A}$ \\
\hline \multirow{3}{*}{ Harvester } & Implementation & $38.45 \mathrm{~A}$ & - & $0.32 \mathrm{~B}$ \\
& Maturing & $35.86 \mathrm{~A}$ & $2.14 \mathrm{~A}$ & $0.78 \mathrm{~A}$ \\
& Stabilization & $38.40 \mathrm{~A}$ & $2.64 \mathrm{~A}$ & $0.64 \mathrm{~A}$ \\
\hline
\end{tabular}

Means followed by the same vertical letter for each machine studied do not differ statistically by the Tukey test at $5 \%$ probability.

Observing the results of the MTBF indicator, it is possible to notice that the feller buncher also increased, with a difference of $7.7 \%$. Although there was a reduction between the implantation and maturation stages, the harvester obtained improvements during the stabilization stage, although it was not possible to detect significant difference by the Tukey test $\left(\mathrm{p}_{\text {value }}<0,05\right)$.

The values presented in Table 2 show that the times obtained for the MTTR indicator in the maturation and stabilization stages obtained a reduction for the feller buncher machine and a slight increase in the times of the other machines, being evidenced in the skidder, that presented average $14 \%$ higher during the stabilization period of the WCM system, however, such results did not present a significant difference by the Tukey test ( $\mathrm{p}_{\text {value }}$ $<0.05)$.

For the MTTR indicator, feller buncher and harvester were the machines that obtained the lowest variation between the maturing and stabilization stages, $1 \%$ and $6 \%$, respectively. This result indicated that, with the exception of skidder, MTTR did not show large variations in results.

The PMI, referring to the percentage of preventive maintenance carried out on the machines, shows that the WCM system allowed a $31 \%$ increase between the implantation and stabilization stages, generating a change in the company's culture, which until then had assumed corrective maintenance practices and preventive maintenance of lubrication, recommended by the automakers. Analyzing machine to machine, it was noticed that there was a reduction of $50 \%$ in corrective maintenance, showing to be statistically different by the Tukey test $\left(\mathrm{p}_{\text {value }}<0,05\right)$.

For the PMI, the machine that presented the greatest difference between the stage of implantation and stabilization was skidder, followed by harvester and then feller buncher. All the machines studied presented a reduction in the percentage of PMI when in the stabilization stage, however, skidder was the machine that showed the smallest reduction.

Observing Table 3, it can be seen that the average maintenance cost of the equipment per hour worked showed an increase of around $6 \%$ during the maturing stage when compared to the stage of implantation. However, in the stabilization stage, it showed a reduction of $15.3 \%$ in relation to the stage of implantation. The machine that evidences such result is the feller buncher, that presented a reduction of $21 \%$ between the maturation and stabilization stages with statistical difference by Tukey test $\left(\mathrm{p}_{\text {value }}<0,05\right)$. 
Tabela 3. Custo de manutenção das máquinas estudadas nos estágios do sistema WCM.

Table 3. Maintenance costs of the machines studied in the WCM stages.

\begin{tabular}{|c|c|c|c|c|c|c|}
\hline Machine & Stage & $\begin{array}{l}\text { Support } \\
\left(\mathbf{R} \$ .^{-1}\right)\end{array}$ & $\begin{array}{c}\text { Material } \\
\left(\mathbf{R} \$ . \mathbf{h}^{-1}\right)\end{array}$ & $\begin{array}{c}\text { Staff (R\$.h } \\
\text { 1) }\end{array}$ & $\begin{array}{l}\text { Service } \\
\left(\mathbf{R} \$ . \mathbf{h}^{-1}\right)\end{array}$ & $\begin{array}{c}\text { Total } \\
\left(\mathbf{R} \$ . \mathbf{h}^{-1}\right)\end{array}$ \\
\hline \multirow{3}{*}{ Feller Buncher } & Implementation & 43.39 & 83.30 & 41.24 & 102.21 & $270.14 \mathrm{~A}$ \\
\hline & Maturing & 37.72 & 119.65 & 32.49 & 105.91 & $295.77 \mathrm{~A}$ \\
\hline & Stabilization & 40.75 & 58.09 & 23.29 & 109.18 & $231.31 \mathrm{~B}$ \\
\hline \multirow{3}{*}{ Skidder } & Implementation & 39.33 & 28.66 & 38.34 & 66.24 & $172.58 \mathrm{~A}$ \\
\hline & Maturing & 37.91 & 39.82 & 31.76 & 69.21 & $178.70 \mathrm{~A}$ \\
\hline & Stabilization & 46.97 & 20.32 & 26.64 & 69.77 & $163.70 \mathrm{~A}$ \\
\hline \multirow{3}{*}{ Harvester } & Implementation & 39.17 & 39.70 & 39.44 & 56.13 & $174.45 \mathrm{~A}$ \\
\hline & Maturing & 40.08 & 51.46 & 35.16 & 71.74 & $198.44 \mathrm{~B}$ \\
\hline & Stabilization & 39.91 & 42.02 & 22.78 & 62.25 & $166.96 \mathrm{~A}$ \\
\hline
\end{tabular}

Means followed by the same vertical letter for each stage studied do not differ statistically by the Tukey test at $5 \%$ probability.

The skidder also presented reduction in maintenance cost per hour worked, however, its results did not present significant difference by the Tukey test $\left(\mathrm{p}_{\text {value }}<0,05\right)$.

For harvester, it can be seen that the stabilization stage had a reduction in maintenance cost of $15.8 \%$ in relation to the maturing stage, which in turn increased by $12.1 \%$ in relation to the period of the WCM system, also showing statistical difference by the Tukey test $\left(\mathrm{p}_{\text {value }}<0,05\right)$.

\section{DISCUSSION}

According to Figure 2, the wood harvesting machines' MA, in most of the machines, increased in response to the investment made with the WCM system implantation, in which was possible to count on a field warehouse with the main turning parts, in a way that when there were some corrective maintenance, the part in question would be available, avoiding unnecessary time to wait for the part to reach the workplace.

Another factor that led to the increase of this indicator, besides the training of mechanics and operators, was the preventive and strategic maintenance accomplishment, in which weekly operations were carried out to check, replace, lubricate, repair and re-install the components of the machinery, allowing greater activity flow, since the number of corrective maintenance has decreased considerably.

As mentioned before, the MA presented increase in most of the machines, however, harvester was the machine that presented different MA behavior. One of the factors that can explain this result is the little variation of the activity of this machine, that worked in a constant rotation, without realizing great displacements and without forcing excessively the machine with abrupt movements. This feature, found only in the processing and loading operations of the wood, brings the operation with few occurrences of failures, generating few corrective maintenances.

In this sense, with the introduction of the WCM system, there was a change in maintenance culture, leading to weekly preventive maintenance. It is important to highlight that this activity, although beneficial, consumes operation time, causing the decreasing of MA percentage, since it represents the time in which the machine has available for operation, disregarding the maintenance times, whether it was corrective or preventive. In this way, the pauses for preventive maintenance ended up influencing the reduction of MA; nonetheless, this result should not be judged in isolation, since the preventive maintenance activity provided the cost reduction of the studied machines.

In general, MA results of the studied machines presented values above $85 \%$, a value close to that obtained by Rocha et al. (2009) and Simões et al. (2014) studying forestry cutting and extraction machines. The causes that most affected the mechanical availability were similar to those found in the study by Rocha et al. (2009), studying a mechanical harvesting system of whole trees, where they comment that the inadequate operation of the machine and incorrect lubrication culminated in the reduction of machines' mechanical availability. In this sense, we

FLORESTA, Curitiba, PR, v. 49, n. 3, p. 533 - 542, jul/set 2019

Dinz, C. C. C. et.al.

ISSN eletrônico 1982-4688

DOI: $10.5380 /$ rf.v49 i3.60013 
complement that the lack of cleaning of the machine and failure to comply with the maintenance procedures also contributes to MA reduction of machines, reducing the reliability of the operation, service life and operational safety.

The mean MA of the feller buncher was $86.9 \%$, being below the results obtained by Pereira et al. (2015), Simões et al. (2014), and Simões and Fenner (2010), 93.0\%, 97.0\% and 91.6\%, respectively. However, these values are obtained by the authors in studies conducted in a short period of time, whereas in this study the data were obtained over a period of 18 months, allowing the obtaining of concrete and reliable results.

In relation to the MTBF, in general, there was an interval increase of machine failures occurrence, being evidenced mainly in skidder (Table 2). Such result was mainly due to the application of preventive maintenance in the equipment evaluated, the training of mechanics and operators and the stock of existing parts in the field warehouse. It is important to emphasize that during the transition period between the stages, that is, at the implantation stage, the employees did not yet have adequate training, and the field warehouse did not have an ideal dimensioning of the parts needed for the activity, directly influencing the reduction of the harvester's MTBF. Therefore, it can be stated that the variation between 25 and 45 hours for the MTBF is considered a good result, given the adverse operating conditions, working up to 18 hours a day during all days of the year.

The MTTR obtained in the stabilization stage showed an increase in the repair time of the failures occurred in the studied machines, except for the feller buncher, which presented reduction of $8.11 \%$. This increase in the repair time, which at first sight seems to be a negative point, was due to the fact that an improvement in the quality of the maintenance activities carried out, the values obtained for skidder and harvester in the variable MTBF are a point that evidenced such information, in which for both machines there was an increase of time in this indicator.

The feller buncher was the machine that demonstrated regularity between the stages of maturation and stabilization, presenting a reduction of $7.4 \%$ in the repair accomplishment time (MTTR). Nevertheless, when checking the variable MTBF of the same machine, a reduction in the mean time between failures (MTBF) is observed, indicating that the maintenance activities carried out on the feller buncher have been reduced regarding services' quality.

The PMI behavior of the evaluated machines in the implantation, maturation and stabilization stages presented in Table 2 shows that from the maturation stage there was an increase of around $40 \%$ in the PMI in relation to the previous stage. This result is explained by the numerous preventive maintenance interventions carried out with the introduction of the WCM system, which resulted in a reduction in the number of failures of all studied machines.

In the WCM system, whenever the components such as hoses, pins, repairs, bearings, pistons, among others, presented wear, they were evaluated during preventive maintenance and in case of necessity these items were replaced, thus reducing the maintenance occurrence (non-scheduled corrective maintenance).

Another relevant point that can be evidenced is the reduction of the PMI in the stabilization stage when compared to the maturation stage, with skidder being the machine that showed the smallest reduction. This fact can be explained by the machines' exposed hydraulic system (feller buncher and harvester), which facilitates the contact between the components with other materials leading to premature wear and, consequently, the rupture of hoses, which were the recurrent failures during the study. This behavior of PMI reduction shows the great complexity of the maintenance of forest machines, being modern, robust and with high technology.

In this way, even with the stops and activities planning in which the machines were being submitted, there were several faults that had not been known until then, so there was no particular part or component in the field warehouse, making the proactive maintenance index to reduce.

Regarding the increase in the maintenance cost between implantation and maturation stages, the same can be explained by the costs of materials and service, where there was investment in operators and mechanics training and purchase of parts and tools for inventory formation, since, over time, it was possible to improve the structure of the warehouse.

For skidder, a reduction in maintenance cost results was identified between the maturation and stabilization stage. This result, although it does not show a significant difference, should be considered relevant, since, with the introduction of a maintenance system based on preventive maintenance, the maintenance cost of the machines was reduced. The values obtained for the maintenance cost of skidder were above the costs observed by Lopes et al. (2014), studying the forest tractor skidder in the extraction of wood, in which they observed an average maintenance cost of $\mathrm{R} \$ 102.30$ per hour worked.

For harvester, the maintenance cost was around $\mathrm{R} \$ 180.00$ per hour worked, mainly due to the costs of materials, services and support, that is, due to the purchase of parts and components and the work of corrective maintenance performed. Simões et al. (2010) found maintenance cost value below the present research, of R\$ 85.00 per hour, while Fernandes et al. (2013) found the value of R\$126.50 per hour worked. 
Several studies have pointed out that the type of maintenance used in wood harvesting machines is very sensitive to the operational conditions of each company, such as the level of training of mechanics and operators, logistics of supply of parts and fuels, size of maintenance structure in the field, among others (MALINOVSKI et al, 2006; FIEDLER et al., 2008; LOPES et al., 2006, FERNANDES et al., 2009, SCHETTINO et al., 2015) which together or alone end up neutralizing any chance of cost reduction and increased MA of wood harvesting machines.

\section{CONCLUSIONS}

- This study presents the analysis of indicators and cost in different phases of the WCM, from its implantation until the moment of its maturation. When WCM was implanted, feller buncher and skidder machines showed increased MA, while harvester showed different behavior, nonetheless, the variation during the WCM phases was not abrupt.

- The MTBF, MTTR and PMI indicators presented the worst results during the WCM implementation stage, due to the change of culture in the company's maintenance sector, which started using a maintenance methodology that uses preventive maintenance as a principle.

- In general, the implantation stage was the one that presented the worst results in relation to the indicators studied, explained by the natural difficulty found at the beginning of each program.

- Although WCM showed an increase during the maturation stage, it was shown that with the change of culture in the maintenance sector, it is possible to reduce the cost of maintenance of the machines, therefore, it is recommended to use the WCM in the maintenance of forest machines.

\section{ACKNOWLEDGMENTS}

This research was financed by Coordination for the Improvement of Higher Level Personnel (CAPES), financial code 001. Special thanks to the forestry company for the support during the data collection. The authors also thank the two anonymous reviewers for making their time available to evaluate the manuscript.

\section{REFERENCES}

BARBOSA, C. E.; BENATO, A. T.; CAVAlHEIRO, A. L.; TOREZAN, J. M. D. Diversity of Regenerating Plants in Reforestations with Araucaria angustifolia (Bertol.) O. Kuntze of 12, 22, 35, and 43 Years of Age in Parana State, Brazil. Restoration Ecology, v. 17, n. 1, p. 60 - 67, 2007.

DARIO, M.; DA SILVA, M.; SACOMANO NETO, M.; PIRES, S. R. I. Indicadores de desempenho, práticas e custos da manutenção na gestão de pneus de uma empresa de transportes. Revista Produção Online, Florianópolis, SC, v. 14, n. 4, p. 1235 - 1269, 2014.

FERNANDES, H. C.; LOPES, S.E.; TEIXEIRA, M. M.; MINETTE, L.J.; RINALDI, P. C. N.; BERNARDES, A. M. Avaliação das características técnica e econômica de um sistema de colheita florestal de árvores inteiras. Scientia Forestalis, v. 37, n.83, p. 225 - 232, 2009

FERNANDES, H. C.; BURLA, E. R.; LEITE, E. S.; MINETTE, L. J. Avaliação técnica e econômica de um "harvester" em diferentes condições de terreno e produtividade da floresta. Scientia Forestalis, v. 41, n. 97 , p. $145-151,2013$.

FIEDLER, N. C.; ROCHA, E. B.; LOPES, E. S. Análise da produtividade de um sistema de colheita de árvores inteiras no Norte do Estado de Goiás. Floresta, v. 38, n. 4, p. 577 - 586, 2008.

GUEDES, L. G.; AMARAL, E. J.; LEITE, E. S.; FERNANDES, H. C.; SANT’ANNA, C. M. Avaliação do desempenho e custos de dois sistemas de cabos aéreos na extração de madeira de eucalipto. Ciência Florestal, v. 27, n. 2, p. $571-580,2017$.

KARDEC, A.; NASCIF, J.; BARONI, T. Gestão estratégica e Técnicas preditivas. Rio de Janeiro: Qualitymark, 1 ed. 2002, 233 p.

LEDOUX, C. B. Mechanized systems for harvesting eastern hardwoods. Newtown Square: U.S. Department of Agriculture, Forest Service, Northern Research Station, 2010. 13p.

FLORESTA, Curitiba, PR, v. 49, n. 3, p. 533 - 542, jul/set 2019.

Dinz, C. C. C. et.al.

ISSN eletrônico 1982-4688

DOI: $10.5380 /$ rf.v49 i3.60013 
LEITE, E.S.; FERNANDES, H. C.; MINETTE, L. J.; SOUZA, A.P.; LEITE, H. G.; GUEDES, I. L. Modelagem do desempenho da extração de madeira pelo "forwarder". Revista Árvore, v. 38, n. 5, p. 879 - 887, 2014.

LOPES, S. E.; FERNANDES, H. C.; SANTOS, N. T.; RINALDI, P. C. N. Avaliação técnica e econômica de uma garra traçadora operando em diferentes produtividades. Scientia Forestalis, v. 36, n. 79, p. 215 - 222, 2008.

LOPES, E. S.; OLIVEIRA, D.; SAMPIETRO, J. A. Influence of wheeles types of a skidder on productivity and cost of the forest harvesting. Floresta, v. 44, n. 1, p. 53 - 62, 2014.

MALINOVSKI, R. A.; MALINOVSKI, R. A.; MALINOVSKI, J. R.; YAMAJI, F. M. Análise das variáveis de influência na produtividade das máquinas de colheita de madeira em função das características físicas do terreno, do povoamento e do planejamento operacional florestal. Floresta, v. 36, n. 2, p. $169-182,2006$.

MISHRA, R. P.; KODALI, R. B.; GUPTA, G.; MUNDRA, N. Development of a framework for implementation of world-class maintenance systems using interpretative structural modeling approach. Procedia CIRP, v. 26, p. $424-429,2015$.

MUCHIRI, P.; PINTELON, L.; GELDERS, L.; MARTIN, H. Development of maintenance function performance measurement framework and indicators. International Journal Of Production Economics, v. 131, n. 1, p. 295 302, 2011.

PACCOLA, J. E. Manutenção e operação de equipamentos móveis. São José dos Campos, SP. 2 ed. 2017. 272 p.

PERREIRA, A. N.; LOPES, E.S.; DIAS, A. N. Análise técnica e de custo do feller buncher e skidder na colheita de madeira em diferentes produtividades do povoamento. Ciência Florestal, v. 25, n. 4, p. 981 - 989, 2015.

ROCHA, E.B.; FIEDLER, N.C.; ALVES, R. T.; LOPES, E. S.; GUIMARÃES, P. P.; PERONI, L. Produtividade e custos de um sistema de colheita de árvores inteiras. Cerne, v. 15, n. 3, p. 372 - 381, 2009.

SCHETTINO, S.; MINETTE, L. J.; SOUZA, A. P. Correlação entre volumetria de florestas de eucalipto e produtividade e custos de máquinas de colheita de madeira. Revista Árvore, v. 39, n. 5, p. 935 - 942, 2015.

SILVA, E. M.; MACHADO, C. C.; MINETTE, L. J.; SOUZA, A. P.; FERNANDES, H. C.; SILVA, M. L.; JACOVINE, L. Avaliação técnica e econômica do corte mecanizado de Pinus SP.com harvester. Revista Árvore, v. 34, n. 4, p. $745-753,2010$.

SIMÕES, D.; FENNER, P. T. Avaliação técnica e econômica do forwarder na extração de madeira em povoamento de eucalipto de primeiro corte. Floresta, v. 40, n. 4, p. 711 - 720, 2010.

SIMÕES, D.; FENNER, P. T.; ESPERANCINI, M. S. T. Avaliação técnica e econômica da colheita de florestas de eucalipto com harvester. Scientia Forestalis, v. 38, n. 88, p. 611-618, 2010.

SIMÕES, D.; FENNER, P.T.; ESPERANCINI, M. S. T. Produtividade e custos do feller-buncher e processador florestal em povoamento de eucalipto de primeiro corte. Ciência Florestal, v. 20, n. 3, p. 621 - 630, 2014.

SPINELLI, R.; WARDB, S. M.; OWENDEC, P. M. A harvest and transport cost model for Eucalyptus spp. fastgrowing short rotation plantations. Biomass and Bioenergy, v. 33, n. 9, p. 1265 - 1270, 2009.

WINKER, M.; HENDERSON, K.; VOLKERTS, J. The computerized maintenance management system an essential tool for world class maintenance. Procedia Engineering, v. 138, p. 413 - 420, 2016.

YAMASHINA, H. Challenge to world class manufacturing. International Journal of Quality of Reliability Management, v. 12, n. 34, p. $30-31,2000$. 